DOI: https://doi.org/10.47405/mjssh.v6i6.822

\begin{tabular}{|c|c|}
\hline 4 & Malaysian Journal of Social Sciences and Humanities (MJSSH) \\
\hline $\begin{array}{l}\text { Malaysian Juoural of } \\
\text { Social ccciecces and }\end{array}$ & Volume 6, Issue 6, June 2021 \\
\hline (MJ-sSH) & e-ISSN : 2504-8562 \\
\hline & $\begin{array}{l}\text { Journal home page: } \\
\text { www.msocialsciences.com }\end{array}$ \\
\hline
\end{tabular}

\title{
Pengurusan Risiko Menurut Perspektif Syarak: Satu Kajian Tinjauan Di Institusi Wakaf Majlis Agama Islam Negeri (MAIN) Terpilih
}

\author{
Wan Mohd Al Faizee Wan Ab Rahaman1, 2, Salmy Edawati Yaacob², Mohamad Sabri Haron², \\ Suhada Ishak ${ }^{3}$ \\ 1 Open University Malaysia (OUM) \\ 2Institut Islam Hadhari, Universiti Kebangsaan Malaysia (UKM) \\ ${ }^{3}$ Berjaya University College
}

Correspondence: Wan Mohd Al Faizee Wan Ab Rahaman (faizee_rahaman@oum.edu.my)

\begin{abstract}
Abstrak
Pengurusan risiko merupakan antara komponen tadbir urus yang baik dan berperanan memastikan objektif dan matlamat institusi tercapai. Risiko dan pengurusan risiko telah menjadi perhatian dalam institusi bermatlamatkan keuntungan seperti syarikat kewangan kerana faktor untung dan rugi. Namun, situasi ini berbeza dengan institusi tidak bermatlamatkan keuntungan yang masih kurang menekankan perihal pengurusan risiko serta dibahaskan dalam konteks semasa. Tambahan pula, syarak telah menekankan perihal risiko dan pengurusan risiko lebih-lebih lagi melibatkan institusi yang berlatar belakangkan Islam seperti wakaf. Justeru itu, kajian ini akan menganalisis kedudukan risiko dan pengurusan risiko dari sudut pandang syarak, seterusnya meneliti keterdedahan risiko serta keperluan pengurusan risiko dalam institusi wakaf. Reka bentuk kajian ini adalah kualitatif dengan menggunakan analisis kandungan. Dapatan kajian mengenal pasti bahawa risiko dan pengurusan risiko telah ditekankan oleh syarak melalui perspektif al-Quran, al-Sunnah, fiqh dan praktikal semasa. Kajian turut mendapati pengurusan wakaf di Malaysia belum terdapat bahagian pengurusan risiko yang khusus dalam organisasi mereka walaupun perbincangan pengurusan risiko dalam institusi tidak bermatlamatkan keuntungan semakin mendapat perhatian. Kajian ini turut mencadangkan pendekatan pengurusan risiko yang lebih menyeluruh dan kontemporari untuk diamalkan dalam kerangka pengurusan risiko institusi wakaf semasa.
\end{abstract}

Kata kunci: pengurusan risiko bersepadu, kewangan sosial Islam, kewangan Islam, non profit organization, endowmen

\section{Risk Management According to Syarak Perspective: An Overview Study on Selected State Islamic Religious Council Waqf Institutions}

\begin{abstract}
Risk management is one of the components of good governance and plays a role in ensuring that the objectives and goals of the institution are achieved. Risk and risk management have become a concern in profit-seeking institutions; such as finance companies. However, the situation is different from nonprofit institutions that are still lack of emphasis on risk management and discussed it in the current context. The Islamic law emphasized on risk and management especially when it involves Islamic institutions such a waqf. Thus, this study will be analyzing the position of risk and risk management from the Islamic point of view, and examine the needs of risk management in waqf institutions. This
\end{abstract}


research utilizes qualitative design by using the content analysis. The findings of the study identified that risk and risk management have been emphasized by the sharia through al-Quran, al-Sunnah, fiqh and the current practices. The study have also found that waqf management in Malaysia does not have specific risk management divisions in their organization although the discussion of risk management in nonprofit organization have gained so much attention. This study also proposed a more comprehensive and contemporary risk management approaches to be adopted in the current risk management framework of waqf institutions.

Keywords: enterprise risk management, Islamic social finance, Islamic finance, nonprofit organization, endowment

\section{Pengenalan}

Risiko dan pengurusan risiko dalam institusi kewangan merupakan komponen penting yang kerap dibahaskan kerana melibatkan aktiviti kewangan dan berperanan untuk menjaga hubungan di antara institusi dan pihak-pihak berkepentingan (El Tiby, 2011; Lahsasna, 2014). Risiko seperti yang didefinisikan oleh Knechel (2002) sebagai kebarangkalian terhadap pendapatan daripada urusan yang tidak menepati sesebuah jangkaan. Oleh itu, pengurusan risiko memainkan peranan untuk mengenal pasti keterdedahan risiko yang menyebabkan kerugian kepada organisasi kemudiannya memilih teknik yang paling sesuai untuk merawat keterdedahan tersebut (Rejda, 2006).

Keterdedahan kepada risiko dalam semua aktiviti merupakan keadaan yang tidak dapat dielakkan. Senario krisis kewangan global pada tahun 2008 sebagai contoh telah membuka mata badan pengawal selia, pengamal dan penyelidik untuk mewujudkan satu pengurusan risiko yang komprehensif bagi menjamin kelangsungan institusi (Said \& Iglesias, 2017). Pengurusan risiko penting di dalam Islam untuk memastikan risiko dapat diuruskan dalam segenap keadaan menurut prinsip-prinsip yang berlandaskan syarak.

Kajian-kajian lepas telah memberikan fokus kepada penilaian risiko dan penyediaan struktur pengurusan risiko (Liebenberg \& Hoyt, 2003). Kebanyakan daripada kajian pengurusan risiko lebih memberikan tumpuan terhadap institusi bermatlamatkan keuntungan berbanding institusi tidak bermatlamatkan keuntungan. Perkembangan semasa menunjukkan institusi tidak bermatlamatkan keuntungan telah memainkan peranan penting dalam memperkukuhkan ekonomi. Wakaf merupakan entiti tidak bermatlamatkan keuntungan dalam konteks di Malaysia. Tambahan pula, pada pembentangan belanjawan kewangan tahun 2020, wakaf telah diangkat untuk menjadi sumber ketiga negara (Belanjawan, 2020). Kedudukan tersebut menyebabkan wakaf perlu untuk diurus dengan efisien dan lestari.

Perbincangan berkaitan wakaf telah diketengahkan dalam pelbagai sudut termasuklah cadangan penambahbaikan pembangunan aset supaya mampu mencapai kelestarian institusi. Walau bagaimanapun, terdapat isu yang membelenggu pengurusan wakaf di Majlis Agama Islam Negeri (MAIN), iaitu isu ketidakcukupan dana untuk tujuan kelangsungan aktiviti wakaf (Sulaiman \& Hasan, 2016). Isu ini dikenal pasti disebabkan oleh keterdedahan kepada risiko yang pelbagai serta tiada bahagian pengurusan risiko khusus dalam organisasi wakaf MAIN (Wan Ab Rahaman et al., 2020).

Kedudukan risiko dalam institusi tidak bermatlamatkan keuntungan seperti wakaf adalah berbeza daripada institusi bermatlamatkan keuntungan. Hal ini kerana, keterdedahan risiko yang dihadapi institusi seperti wakaf, lebih kompleks disebabkan oleh objektif, matlamat, keadaan persekitaran, ciriciri dan hubungan antara pemegang-pemegang berkepentingan yang pelbagai (Gronbjerg, 1991). Situasi ini turut mempengaruhi amalan pendekatan pengurusan risiko yang akan dijalankan. Oleh sebab pengurusan risiko adalah komponen penting dalam sesebuah tadbir urus, kedudukan pengurusan risiko dalam konteks syarak akan diperhalusi dalam kajian ini, memandangkan wakaf mempunyai elemen agama yang mengikat aktiviti pengurusannya. Selain itu, analisis turut melihat struktur 
organisasi MAIN terpilih dan kemudiannya mencadangkan pendekatan pengurusan risiko bersesuaian dalam konteks semasa.

\section{Sorotan Literatur}

Perbahasan risiko telah menjadi tumpuan dalam kalangan akademi Barat seperti yang dijalankan oleh Thompson (1986); Trimpop (1994) dan Althaus (2005). Dalam literatur sejarah, risiko digunakan sebagai kerangka untuk menganalisis peristiwa dan isu. Konsep risiko dikesan pada kurun ke-17 dalam konteks perjudian dan membawa kepada maksud kebarangkalian sesuatu peristiwa yang berlaku dengan skala kerugian atau keuntungan yang terlibat. Sehingga hari ini, masih tidak terdapat definisi khusus bagi risiko, kecuali ditakrifkan berdasarkan sektor atau bidang-bidang berkaitan seperti insurans, ekonomi, statistik dan lain-lain (Redzuan et al., 2006). Mary Douglas selanjutnya mendapati konotasi berkaitan dengan risiko telah berubah mengikut perkembangan masa (Mohd Noor et al., 2018).

Bagi mendapatkan maksud risiko yang lebih mendalam dan tersusun, maksud risiko disoroti berdasarkan konteks ekonomi dan kewangan, iaitu risiko adalah proses analisis pengagihan pulangan korporat (Fisher, 1983). Bhatti dan Misman (2012) memberikan definisi risiko dalam ekonomi sebagai ketidaktentuan yang wujud terhadap hasil mendatang yang mana kemungkinan pendapatan lebih daripada jangkaan dan sumber yang tidak diketahui. Tambahan pula, risiko adalah elemen yang tidak dapat dielakkan dalam aktiviti ekonomi dan memainkan peranan dalam pengantaraan kewangan (Akkizidis \& Khandelwal, 2008). Kategori risiko adalah bergantung kepada hasil, kerugian, dan keadaan setiap risiko dan ia turut bergantung kepada penglibatan kontrak, kemudahan dan kesukaran untuk dihadapi oleh setiap individu (Elsefy, 2007; Mohd Razif \& Mohamad, 2011).

Perbincangan maksud risiko berdasarkan kepada aktiviti atau bidang turut telah mempengaruhi pembahagian risiko. Risiko dalam ekonomi sebagai contoh telah dibahagikan kepada risiko sistematik dan tidak sistematik (Mohd Razif \& Mohamad, 2011). Risiko sistematik merujuk kepada pergerakan keseluruhan ekonomi, pertumbuhan dalam industri dan segala pertimbangan yang memberikan kesan terhadap tahap keseluruhan harga seperti perubahan kadar keuntungan, kemelesetan dan peperangan. Faktor-faktor yang membawa kepada risiko tidak sistematik adalah pengurusan yang lemah, kedudukan kewangan dan pemerolehan. Oleh itu, risiko-risiko ini boleh diperoleh melalui pembacaan dan analisis terhadap data syarikat.

Risiko dalam institusi insurans pula dibahagikan kepada risiko spekulatif dan risiko tulen. Risiko spekulatif digambarkan keadaan yang memungkinkan berlakunya kerugian dan keuntungan. Risiko tulen pula adalah keadaan di mana kerugian sahaja berlaku dan tiada keuntungan akan diperoleh (Redzuan et al., 2006). Khan dan Ahmed (2001) berikutnya telah mengkategorikan risiko kepada risiko perniagaan dan risiko kewangan. Menurut mereka, risiko perniagaan turut dikenali dengan risiko primer (al-Saati, 2003; Dusuki \& Smolo, 2009) muncul apabila tingkah laku perniagaan seperti risiko pasaran, risiko kredit dan risiko kecairan. Risiko kewangan pula melibatkan kemungkinan pulangan pelaburan yang rendah daripada setiap pulangan yang dijangka dan muncul disebabkan oleh pergerakan pemboleh ubah kewangan seperti risiko kadar pertukaran mata wang asing, risiko ekuiti, risiko kadar keuntungan dan risiko harga komoditi. Ketidakcekapan pengurusan risiko kerap dikaitkan dengan prosedur formulasi pengurusan risiko yang lemah termasuklah pengenalpastian risiko, analisis dan kawalan (Carr \& Tah, 2001), kelompangan kesinambungan pengurusan risiko dalam tahap yang berbeza, kelemahan integrasi di antara pengurusan risiko dan kelompangan interaksi di antara pihak yang berbeza (Liu et al., 2007).

Keterdedahan kepada risiko memerlukan kaedah dan pendekatan untuk menguruskan risiko-risiko tersebut. Pengurusan risiko dikenal pasti mampu untuk memandu pengurusan projek yang baik, penggunaan sumber yang efektif dan penyampaian perkhidmatan yang terbaik (Collier \& Woods, 2011). CAS (2003) menghuraikan maksud pengurusan risiko sebagai satu proses untuk mengenal pasti, menganalisis, menilai, menghalang, mengutamakan, memantau dan menilai semula risiko. Pengurusan risiko turut dirujuk kepada proses menyeluruh bagi institusi untuk mematuhi maksud dan 
ketetapan strategi, mengenal pasti jenis risiko yang memberi kesan kepada institusi, impak risiko dalam nilai kewangan, dan kemungkinan kawalan dalaman yang perlu diimplementasikan bagi menguruskan sebarang potensi ancaman (Rahman et al., 2014). Objektif utama pengurusan risiko menjurus kepada aktiviti perekonomian yang tidak boleh dinafikan bagi mewujudkan kewangan yang menyeluruh kemudiannya berusaha untuk memaksimumkan keuntungan (Mohd Razif \& Mohamad, 2011). Pendekatan membuang semua risiko adalah mustahil (Habegger, 2008) kerana berkemungkinan berkaitan dengan peluang dan penting untuk meneruskan usaha-usaha inovasi, pertumbuhan ekonomi dan perkembangan sosial. Pengurusan risiko telah mula diadaptasi oleh pelbagai sektor seperti percukaian, sumber manusia, perolehan dan logistik (Hopkin, 2002).

Pengurusan risiko berfungsi secara asasnya untuk mengaplikasikan prosedur yang boleh meminimumkan keterdedahan kepada risiko atau impak kewangan yang negatif (Vaughan, 1997). Pengurusan risiko telah dikenal pasti pada lewat tahun 1940 dan dikenali dengan pendekatan silo/tradisional iaitu pengurusan risiko berasaskan kepada risiko individu serta kaedah yang diguna pakai tidak menyeluruh (Dickinson, 2001). Terdapat hanya dua jenis risiko yang diuruskan pada waktu tersebut, iaitu risiko kewangan dan risiko bukan kewangan (Culp, 2002). Proses pengurusan risiko menurut Van Staveren (2009) terdiri daripada 5 tahap iaitu penentuan objektif, pengenalpastian risiko, penilaian risiko, pertimbangan alternatif dan pemilihan alat merawat risiko dan pelaksanaan dan penilaian.

Seterusnya, perkembangan pengurusan risiko dibahaskan berdasarkan pendekatan atau strategik seperti teknik kepelbagaian dalam pengurusan risiko oleh Markowitz pada tahun 1952, kemudiannya Sharpe dan Lintner telah memperkenalkan Capital Aset Pricing Model (CAPM) pada tahun 1964. Stephen Ross pula telah memperkenalkan teori non-arbitrage pada tahun 1976 bagi membuat andaian terhadap hubungan antara pulangan dalam portfolio dan pulangan bagi aset individu melalui kombinasi linear dengan pemboleh ubah makroekonomi. Bagi membangunkan item-item portfolio bersama-sama karakter tertentu seperti risiko, Fama dan French telah membangunkan model faktorfaktor risiko lain pada tahun 1992. Selain itu penggunaan value-at-risk (VaR) yang dibangunkan oleh JP Morgan pada tahun 1994 telah menjadi salah satu pendekatan pengurusan risiko.

Kemudiannya, Vaughan (1997) telah memperkenalkan teknik berhadapan dengan risiko yang dikenali dengan pengawalan risiko (risk control) dan pembiayaan risiko (risk financing). Risiko akan dikurangkan melalui teknik pengawalan risiko kerana organisasi akan mengelak daripada menerima sebarang aktiviti yang terdedah kepada peningkatan risiko. Kaedah yang diguna pakai adalah pengelakan risiko (risk avoidance) melalui pencegahan kerugian (loss prevention) dan usaha pengawalan (control efforts). Pembiayaan risiko pula memberikan fokus terhadap jaminan kewujudan dana bagi berhadapan dengan sebarang kerugian. Pendekatan dalam teknik pembiayaan risiko adalah pengekalan (rentention) atau pemindahan (transfer). Pendekatan pengekalan dilakukan apabila risiko diabaikan atau pengukuran sebenar tidak mampu diadaptasi.

Teknik-teknik yang di aplikasi dalam kalangan operator takaful pula terdiri daripada penilaian risiko kendiri, pengurusan liabiliti aset, modal kesolvenan, retakaful atau program pemindahan risiko dan indikator kunci utama risiko telah memberikan amaran kepada perniagaan terhadap kebarangkalian risiko dan sebarang kerugian dalam perniagaan.

Kini, terdapat pendekatan yang lebih holistik dan bersifat integrasi dikenali dengan enterprise risk management (ERM) dan telah digalakkan dalam pengurusan saham (Shimpi \& Lowe, 2006). Pendekatan ini telah dibahaskan oleh ramai pengkaji dan dilihat mempunyai kemampuan untuk menguruskan risiko-risiko yang pelbagai setelah penyusunan organisasi institusi diberikan tumpuan terlebih dahulu (COSO, 2004). 


\section{Metod Kajian}

Kajian ini adalah kajian kualitatif dengan menggunakan pendekatan analisis kandungan. Data diperoleh daripada artikel jurnal serta laman sesawang Majlis Agama Islam Negeri (MAIN) terpilih mengikut zon di semenanjung Malaysia.

\section{Risiko dan Pengurusan Risiko Menurut Perspektif Islam}

Risiko berdasarkan sudut pandang orang-orang Islam telah diterjemahkan dalam konteks yang lebih jauh, iaitu kebarangkalian kehidupan selepas meninggal dunia. Situasi tersebut merujuk kepada tindakan, tingkah laku dan amalan yang baik yang bakal menentukan baik dan buruk kehidupan mereka di dunia dan akhirat. Perlindungan terhadap sebarang risiko yang berbahaya terletak dalam objektif pengurusan risiko tertinggi dalam objektif pensyariatan Islam.

Bagi mendapatkan kefahaman risiko dari perspektif Islam, perbincangan risiko dan pengurusan risiko dibahagikan kepada tiga bahagian, iaitu risiko menurut al-Quran, al-Sunnah dan fikah semasa. Perkataan risiko telah digariskan dalam al-Quran berdasarkan beberapa istilah dan membawa kepada pengertian yang berkaitan definisi risiko seperti yang telah dibahaskan sebelum ini. Berdasarkan kepada Firman Allah dalam surah al-Baqarah 2:195 yang bermaksud:

\section{"dan belanjakanlah (harta bendamu) di jalan Allah, dan janganlah kamu menjatuhkan dirimu sendiri ke dalam kebinasaan, dan berbuat baiklah, karena Sesungguhnya Allah menyukai orang-orang yang berbuat baik"}

Ayat ini telah menunjukkan penegasan Allah SWT melalui larangan membiarkan diri dalam kebinasaan. Perkataan kebinasaan mempunyai maksud yang hampir dengan maksud risiko iaitu terdedah kepada bahaya dan kemusnahan. Konsep larangan ini merupakan halangan terhadap sesuatu keadaan yang membawa kepada natijah yang negatif (Kathir, 1999). Namun, risiko tidak dilihat sebagai faktor larangan dalam kontrak selagi tidak mendatangkan isu gharar. Allah SWT dan Rasulullah SAW membenarkan semua risiko kerana tidak semua transaksi terlibat dengan kerugian. Perkara yang dilarang berkaitan risiko apabila melibatkan pemilikan harta yang tidak sah walaupun risiko tidak wujud di dalam aktiviti tersebut (Ibn Taimīyyah, 1987). Menurut Ibn Taimīyyah, larangan terhadap risiko hanya melibatkan ciri-ciri mudarat terhadap aset tetapi tidak melibatkan aktiviti berisiko (Ibn Taimīyyah, 1987). Tambahan pula, Al- Suwailem (2013) menegaskan bahawa pendedahan terhadap risiko berlebihan adalah tidak diingini kerana saiz kemungkinan kerugian wujud, dan jika terus berlaku kesannya akan mengakibatkan bahaya kepada organisasi sosial.

Perbincangan risiko dalam konteks al-Quran diperkukuhkan dengan hadis Rasulullah SAW sebagaimana yang diriwayatkan oleh Abu Dawud:

الخر اج بالضمان

Sesungguhnya keuntungan berdasarkan kepada kadar kerugian atau risiko yang juga perlu ditanggung ${ }^{1}$.

Hadis ini berdasarkan kepada peristiwa yang diriwayatkan oleh Ibn Majah:

"Sesungguhnya seorang lelaki membeli seorang budak dan mendapati terdapat kecacatan dan dia mengembalikan dan menemui Nabi SAW dan berkata: Ya Rasulullah, pembeli telah mengambil manfaat daripada budakku. Rasulullah menjawab, dapatan itu sesuai dengan tanggungan"2.

\footnotetext{
${ }^{1}$ Abu Dawud, Kitab al-Ash'ath al-Sajastani, Abu Dawud Sulayman, Sunan Abi Dawud, Riyad: Maktabah al-Ma'arif li al-nashr wa al-tawzi'

${ }^{2}$ Sahih Sunan Ibn Majah, Muhammad Nasir al-Din al-Albani, Maktabah Tarbiyah al-Arabi liduwal al-Khalij.
} 
Dapatan daripada hadis tersebut merujuk kepada hak mendapatkan sesuatu hasil, maka terdapat keharusan untuk menanggung kerugian. Abu Ubaid menjelaskan maksud al-kharāj dalam hadis tersebut merujuk kepada manfaat terhadap budak tersebut. Pembeli tersebut telah menggunakan budak yang dibeli dan setelah beberapa waktu, dia mendapati kecacatan dan mengembalikan kepada penjual dan dia mendapatkan kembalikan keseluruhan harga kerana budak tersebut di bawah tanggungannya. Jika budak itu rosak, rosak sebahagian hartanya (Zaidan, 2008). Menurut al-Zarkashi, sesuatu yang keluar dari sesuatu berupa barangan, manfaat atau dapatan adalah milik pembeli seperti ganti atas apa yang wajib kepadanya berupa tanggungan pemilikannya. Dapatan ini menjadi haknya agar dia memperoleh keuntungan sewaktu berhadapan kerugian (Zaidan, 2008).

Oleh itu, jika sesuatu yang biasanya ditanggung oleh manusia rosak, maka kerosakan itu kembali kepadanya. Sebagai balasan, manfaat-manfaatnya adalah khusus untuknya sama ada dia memanfaatkan atau mendapatkan hasil daripadanya (Zaidan, 2008). Majalah al-Ahkam al-Adliyah no. 85 turut menjelaskan sesiapa yang menanggung sesuatu dan ia rosak maka ia berhak untuk memanfaatkannya dalam tanggungan. Berdasarkan kepada hadis yang telah dibincangkan, sarjana Islam telah menghasilkan satu formula (kaedah) untuk membahaskan perihal risiko dalam konteks sudut padang fikah. Kaedah al-ghurm bi al-ghunm yang bermaksud keuntungan (hasil pelaburan) diperoleh dengan menghadapi risiko (dan jaminan barang yang dijual adalah selamat iaitu bermakna tiada untung tetap dijanjikan) (Al-Zarqa', 1980).

Majallah al-Ahkam al-Adliyyah no.87 menjelaskan denda itu dengan perolehan atau denda itu seimbang dengan perolehannya bermaksud orang yang memperoleh manfaat ke atas sesuatu akan menanggung kerugiannya. Kaedah hukum ini adalah selari dengan maksud hadis yang telah dihuraikan iaitu apabila seseorang hendak menanggung kerugian sahaja yang berhak mendapat keuntungan. Risiko perlu ditanggung jika berkehendak kepada keuntungan dari modal-modal yang dilaburkan (Ayub, 2007). Situasi tersebut selari dengan konsep risiko dan untung, iaitu high risk high return, low risk low return. Oleh itu, perkaitan rapat antara untung dan risiko ditonjolkan dalam setiap pelaburan dan perniagaan.

Berdasarkan kepada perbincangan risiko dari kaca mata al-Quran dan al-Hadis, risiko telah dibahagikan kepada tiga perbincangan. Perbincangan pertama merujuk kepada perbahasan risiko dalam konteks terminologi bahasa Arab. Elgari (2003) dikenal pasti orang pertama membincangkan risiko dalam konteks kewangan Islam secara sistematik dengan menghuraikan konsep mukhātarah sebagai situasi yang melibatkan kebarangkalian penyimpangan kaedah yang membawa kepada jangkaan keputusan dan kebarangkalian rugi. Terminologi tersebut turut bermaksud sesuatu yang tidak diketahui pasti benar atau tidak atau sesuatu yang mengundang atau menempuh bahaya Beliau telah mengguna pakai terminologi bahasa Arab dengan memperkenalkan perkataan khatr yang selari dengan maksud risk dalam bahasa Inggeris (Mohd Razif \& Mohamad, 2011). Risiko turut memberi maksud sebagai peristiwa masa hadapan yang tidak menentu yang boleh mempengaruhi pencapaian objektif sesebuah perniagaan termasuklah strategi, pengoperasian dan pematuhan. Terma ini diperkenalkan dalam disiplin ilmu kewangan Islam kerana kesan dan akibat dalam aktiviti kewangan Islam adalah selari dengan maksud khatr yang telah dihuraikan oleh Ibn Manzur (2002) sebagai keterdedahan kepada kerosakan atau hampir kepada kebinasaan. Definisi daripada Elgari telah memberikan penjelasan berhubung risiko yang terdiri daripada dua elemen iaitu tindakan manusia sewaktu membuat keputusan untuk menyimpang daripada tujuan sebenar dan keadaan yang mendorong kepada tindakan manusia menyimpang daripada jalan sebenar. Oleh itu, Elgari (2003) telah menyimpulkan bahawa sebarang risiko yang disebabkan oleh manusia dilihat datangnya dari Allah SWT dan manusia harus meredainya.

Perbahasan kedua dipelopori oleh Althaus (2005) dan Aygun (2007) yang menghuraikan perkataan risiko berdasarkan kepada perkataan bahasa Arab iaitu rizq atau risq dan membawa maksud pengagihan atau sebarang peruntukan yang ditetapkan oleh Allah.

Perbincangan ketiga telah melibatkan beberapa nama besar dalam kewangan Islam iaitu Elgari (2003), Dusuki dan Smolo (2009), Abdullah et al. (2011), Ismail \& Ahmad (2010) dan Bougatef (2015) yang telah menghuraikan maksud risiko berdasarkan kaedah fiqh (qawaid fiqhiyyah). Perbincangan ini lebih 
sistematik kerana mendasari kepada hubungan di antara risiko dan pulangan dan untuk itu, hubungan di antara keuntungan dan kerugian adalah berdasarkan kaedah fiqh dan hadis yang masyhur iaitu "alghunm bi al-ghurmi" dan "al-kharaj bi al-dāman". Tambahan pula, menurut Dusuki dan Smolo (2009), risiko dalam situasi ini adalah wajib wujud sebagaimana (Rosly, 2005) menjelaskan apabila seorang penjual yang perlu untuk menanggung risiko kerugian kerana kerosakan atau penurunan harga barang sebelum barang yang hendak dijual berpindah kepada pemiliknya (pembeli). Keperluan untuk menanggung risiko dalam konteks ini merupakan pra syarat bagi sesebuah transaksi perniagaan.

Perkataan dāman di dalam hadis merujuk kepada beberapa maksud antaranya adalah bermaksud kafalah iaitu kebertanggungjawaban di antara individu dengan individu lain. Elgari menjelaskan maksud daman merujuk kepada pandangan mazhab Hanafi sebagai ketetapan untuk membayar pampasan disebabkan oleh kerosakan. Pernyataan ini telah dipersetujui oleh kebanyakkan sarjana fiqh iaitu keperluan menanggung risiko bagi mendapatkan kecukupan pulangan.

Al-Suwailem (2013) pula menjelaskan perihal keterdedahan kepada risiko yang berlebihan adalah tidak digalakkan kerana kebarangkalian kerugian adalah sangat besar dan akan memberikan impak buruk. Tambahan pula, perbahasan risiko perlu selari dengan perbincangan larangan memperoleh keuntungan tanpa tanggungan dan larangan terhadap transaksi yang melibatkan ketidaktentuan (gharar). Antara risiko yang dilarang apabila terdapat elemen gharar yang jelas seperti perjudian kerana telah dilarang dengan jelas dalam undang-undang syarak (Al-Suwailem, 2001). Sarjana fiqh telah bersetuju bahawa gharar fāhish akan menyebabkan kontrak terbatal terutama melibatkan uqud mu'āwadat (Mohd Razif \& Mohamad, 2011).

Perbincangan risiko dalam konteks institusi kewangan Islam bukan sahaja mengiktiraf kewujudan risiko bahkan menggalakkan aktiviti mengawal dan mengurus risiko bagi mencapai objektif pensyariatan iaitu pemuliharaan harta (Mohd Razif \& Mohamad, 2011). Antara faktor yang mempengaruhi kewujudan risiko dan kontrak adalah struktur produk, risiko perniagaan, risiko kewangan dan kualiti pengurusan (Khadijah Iskandar, 2016).

Ibn Taimiyah telah membahagikan risiko kepada dua kumpulan iaitu risiko komersial yang melibatkan pembelian komoditi oleh seseorang untuk tujuan penjualan bagi mendapatkan keuntungan dan mengharapkan kebaikan dari Allah seperti yang berlaku dalam sektor perdagangan. Kumpulan kedua pula adalah risiko perjudian iaitu proses pemerolehan kekayaan tanpa sebarang usaha (Ibn Taimiyyah, 1996).

Keunikan risiko telah diperhalusi dalam konteks kewangan Islam apabila institusi ini menawarkan produk dan perkhidmatan berasaskan Islam dan telah mengetengahkan risiko yang dikenali dengan risiko unik. Risiko unik adalah merupakan tindak balas terhadap percampuran risiko yang pelbagai dalam institusi-institusi kewangan Islam dan pengaturan perkongsian risiko dan terhasil daripada kontrak pembentukan instrumen (Sundarajan, 2005).

Dusuki (2009) pula telah membahagikan kumpulan risiko kepada risiko yang mesti ditanggung, risiko yang diharamkan dan risiko yang boleh dielakkan. Perbincangan pengkategorian risiko ini banyak dibahaskan dalam institusi kewangan Islam dan antara kategori risiko yang diketengahkan adalah risiko kewangan (financial risk), risiko perniagaan (business risk), risiko perbendaharaan (treasury risk) dan risiko tadbir urus (governance risk). Risiko perniagaan muncul daripada tabiat perniagaan seperti risiko pasar, risiko kredit dan risiko kecairan (Khan \& Ahmed, 2001). Risiko kewangan pula daripada kebarangkalian kerugian dalam pasaran kewangan disebabkan oleh pergerakan pemboleh ubah kewangan (financial varaibles) seperti risiko kadar tukaran wang asing, risiko ekuiti, risiko kadar faedah dan risiko harga komoditi (Jorion, 1996). Risiko perbendaharaan pula terdiri daripada risiko pengurusan liabiliti aset dan risiko lindung nilai. Risiko urus tadbir dibahagikan kepada risiko operasi, risiko reputasi, risiko transparensi, risiko kepatuhan syariah dan risiko fiduisari. Islamic Financial Service Board (IFSB) pula telah mengklasifikasikan enam kategori risiko iaitu risiko pengoperasian, risiko kredit, risiko pelaburan ekuiti, risiko pasaran, risiko kecairan dan risiko kadar pulangan (IFS, 2004). 
Kewujudan risiko dalam transaksi kewangan terutama dalam institusi kewangan Islam telah mewujudkan pelbagai perspektif. Perbankan Islam telah dikenal pasti merupakan platform yang lebih selamat daripada perbankan konvensional disebabkan oleh aktiviti kewangan yang tidak didasari dengan kadar keuntungan. Oleh sebab pengurusan produk dalam kewangan Islam berasaskan kaedah tambah harga, pendekatan pengurangan risiko diperlukan. Setelah berlaku pelbagai krisis dalam dunia ekonomi dan kewangan, pengurusan risiko telah menjadi sebahagian penting komponen tadbir urus bagi menyusun dan mengawal atur aktiviti institusi.

Ahmed (2010) telah memberikan definisi pengurusan risiko sebagai fokus strategi, menggariskan perkara yang memerlukan sokongan, dan dikaitkan dengan sistem dan proses yang memerlukan penempatan. Proses pengurusan risiko melibatkan aktiviti mengenal pasti, menilai dan mengatur kepentingan risiko dan dilaksanakan secara berasingan untuk tujuan penganalisisan. Proses ini kemudiannya diikuti oleh penggunaan sumber yang teratur dan ekonomi bagi mengurangkan, memantau dan mengawal kemungkinan yang tidak diingini atau bagi memaksimumkan peluang (Hubbard, 2009). Aktiviti menguruskan risiko telah diterima pakai dalam Islam (Nurhafiza, 2015). Kepentingan untuk menguruskan risiko telah digariskan di dalam al-Quran melalui surah al-Baqarah 2:195:

"Dan janganlah kamu sengaja mencampakkan diri kamu dalam bahaya kebinasaan dan perbaikilah perbuatan kamu, sesungguhnya Allah mengasihi orang-orang yang berusaha memperbaiki amalannya".

Larangan Allah SWT dalam ayat di atas merujuk kepada larangan daripada terlibat dalam kebinasaan dan dapat difahami keterlibatan dengan aktiviti yang terdedah kepada risiko. Konteks ayat tersebut diperincikan dengan hadis Rasulullah SAW dengan seorang lelaki Badwi. Peristiwa tersebut berkaitan persoalan lelaki Badwi tersebut tentang untanya yang perlu dibiarkan tanpa diikat dan sekadar bertawakal kepada Allah SWT. Rasulullah SAW telah meminta lelaki itu mengikat untanya dengan tali supaya tidak hilang kemudian baru bertawakal kepada Allah SWT.

Selain itu, ayat surah al-Baqarah 2:282 turut menjelaskan konsep pengurusan risiko melalui aktiviti catatan hutang. Aktiviti pengurusan risiko turut dibahaskan berdasarkan kisah analisis mimpi penguasa Mesir oleh Nabi Yusuf melalui surah Yusuf 46-49. Saranan Nabi Yusuf supaya bersedia dengan bekalan tanaman untuk tempoh 7 tahun kerana negara Mesir bakal berhadapan dengan musim kemarau dan ternyata saranan tersebut telah mengelakkan rakyat Mesir daripada kebuluran sewaktu kemarau. Walaupun konsep ini berbeza dengan pengurusan risiko kewangan, namun keputusan yang dijalankan dengan terancang dapat mengurangkan keterdedahan risiko yang besar.

Sistem dan prosedur pengurusan risiko bukan satu perkara yang baharu (Liu et al., 2007). Keperluan kepada sistem dan prosedur pengurusan risiko telah digariskan oleh al-Quran melalui kisah strategi memasuki Mesir oleh Nabi Yaakub kepada anak-anaknya (Yusuf, 12:67). Nabi Yaakub telah menasihati anak-anaknya supaya merancang dan mencari jalan alternatif yang berbeza-beza untuk memasuki kota Mesir agar tidak menempuh bahaya ditangkap oleh penguasa Mesir.

Syarak memberi penekanan terhadap aktiviti pengurusan risiko terutama apabila melibatkan transaksi kewangan. Tujuan ini penting disebabkan oleh hubungan aktiviti pengurusan kewangan dengan objektif pensyariatan Islam iaitu hifz al-Mal (pemeliharaan harta). Objektif ini dapat dicapai dengan mempraktikkan sistem kewangan Islam yang berasaskan kepada prinsip undang-undang dan shariah. Contohnya, dalam urusan mudārabah, iaitu kontrak muamalat yang membenarkan perincian pelaburan projek bagi mengurangkan risiko kerugian.

Pengkaji-pengkaji seperti Al-Suwailem (2013); Akkizidis dan Khandelwal (2008); Elgari (2003); Eid dan Kamal (2012); Febianto (2012); Greuning dan Iqbal (2008); Khan dan Ahmed (2001); Siddiqui (2008); Sundararajan dan Errico (2002) dan Tariq (2004) telah memberikan fokus terhadap pengawalan risiko dan kaedah untuk menguruskan risiko bertujuan untuk mengurangkan kesan buruk sewaktu membuat keputusan dalam institusi kewangan Islam. Aktiviti menguruskan risiko adalah aktiviti penting dalam entiti korporat dan pendekatan pengurusan risiko dilakukan melalui pembacaan 
dan analisis data dan maklumat syarikat (Ramli, 2000). Selain itu, risiko ini dapat diuruskan melalui kepelbagaian dalam portfolio pelaburan.

Institusi perbankan kebiasaannya mempunyai dua pendekatan strategi pengurusan risiko iaitu melibatkan aktiviti penguraian risiko dan pengumpulan risiko. Kedua-dua strategi ini diguna pakai oleh bank sewaktu menguruskan risiko pasaran dan risiko kredit. BNM (2018) telah mengemukakan rangka awal pengurusan risiko syariah institusi kewangan Islam iaitu mengenal pasti, mengukur, memantau dan mengawal daripada berlaku elemen yang tidak mematuhi shariah. Kerangka tersebut terdiri daripada jawatankuasa shariah yang memantau fungsi-fungsi berkaitan shariah, audit shariah, pengurusan risiko shariah dan kajian-kajian shariah (BNM, 2011). Basel (2004) turut mengetengahkan garis panduan pengurusan risiko bagi mengawal pelaburan yang dijalankan oleh institusi-institusi kewangan. Justeru, pengurusan risiko shariah berfungsi untuk memantau dan mengawal secara sistematik seterusnya membuat penilaian terhadap risiko bagi mengelak sebarang ketidakpatuhan shariah.

\section{Perbincangan dan Hasil Kajian}

Menurut Anheier (2005) kesedaran terhadap keperluan dan kepentingan menguruskan risiko dalam kalangan organisasi turut melibatkan institusi tidak bermatlamatkan keuntungan kerana keutamaan organisasi ini untuk mencapai objektif, matlamat dan misi yang telah ditetapkan. Hal ini selaras dengan fokus pengurusan risiko iaitu menjangkakan risiko yang bakal wujud dan mengelakkan atau meminimumkan impak negatif berdasarkan analisis terhadap risiko. Walau bagaimanapun, seperti yang telah dibahaskan, tidak semua risiko adalah negatif kerana terdapat risiko-risiko yang boleh memberikan peluang kepada organisasi dari sudut pulangan yang menguntungkan.

Boas (2012) telah mendefinisikan risiko dalam institusi tidak bermatlamatkan keuntungan sebagai impak negatif yang mengekang daripada misi, objektif, strategik untuk dicapai. Antara isu yang biasa membelenggu entiti seperti organisasi tidak bermatlamatkan keuntungan adalah kekangan kakitangan berlatar belakangkan perakaunan, tiada kehendak pemilikan yang jelas, tiada objektif yang jelas dan mantap menyebabkan pengoperasian entiti tersebut tidak mampu untuk menunjukkan elemen ketelusan (Othman \& Ameer, 2014). Matan dan Hartnett (2011) telah mengenal pasti enam keadaan biasa yang mempunyai potensi yang tinggi dan berisiko iaitu peristiwa dan aktiviti, kutipan dana awam, sukarelawan, kewangan, kakitangan, geran yang terhad dan reputasi. Perbincangan kategori risiko dalam institusi tidak bermatlamatkan keuntungan (ITBK) adalah masih sedikit. Oleh sebab fokus ITBK adalah berbeza dengan IBK, kerumitan tersebut disebabkan oleh kepelbagaian risiko yang dihadapi oleh ITBK. Justeru, pengkategorian risiko perlu dilihat kepada objektif dan misi organisasi tersebut.

Perbincangan risiko yang dihadapi oleh institusi tidak bermatlamatkan keuntungan (ITBK) secara komprehensif dan mendalam di peringkat antarabangsa adalah masih kurang (Clary, 1997; Iwankiewicz-Rak, 2006; Jackson, 2010). Kebanyakan daripada pengkaji melihat risiko yang dihadapi oleh ITBK dikaitkan dengan risiko perkongsian, kerjasama, atau pakatan (Sollis, 1995), risiko reputasi, risiko kewangan (Bowman, Keating \& Hager, 2007; Kearns, 2007; Trussel, Patrick, 2009). Kategori risiko yang turut diteroka adalah risiko aset (Duncan, 2008), risiko undang-undang, risiko kerugian, risiko kepatuhan, risiko reputasi (Zapadka, 2007), risiko organisasi, individu dan masa (Mitchell, 1995) dan risiko penerbitan (West \& Sargeant 2004).

Terdapat dua alasan ITBK memerlukan kepada pengurusan risiko, iaitu keinginan organisasi terbabit untuk memelihara diri mereka daripada hasil yang akan membahayakan misi dan objektif organisasi. Selain itu, pengurusan risiko membantu dalam mengenal pasti pilihan dan alternatif yang mampu menjayakan misi dan objektif organisasi (Head \& Herman, 2002; Ostrower, 2007). Kunci utama pengurusan risiko dalam ITBK adalah tertakluk kepada pelbagai bentuk seperti kewangan, individu, program, perbelanjaan modal dan semua risiko yang berkaitan wujud disebabkan keterlibatan dengan perubahan, kesulitan, ketidaktentuan ekonomi, politik dan sosial. Othman dan Ameer (2014) 
menekankan keperluan untuk mewujudkan pengurusan risiko dalam institusi tidak bermatlamatkan keuntungan.

Trivunovic et al., (2011) menegaskan bahawa kebanyakan penyumbang antarabangsa dan institut tidak bermatlamatkan keuntungan tidak mengaplikasikan kaedah yang komprehensif untuk mengatasi kerosakan yang dijangka dan yang tidak dijangka disebabkan oleh risiko. Young (2009) mendapati ITBK tidak meletakkan pengurusan risiko secara menyeluruh di dalam organisasi mereka. Beliau turut mendapati bahawa, ITBK tidak mampu untuk mengambil keputusan yang konsekuen di tahap strategik walaupun kelihatan ITBK melaksanakan pengurusan risiko dalam konteks penolakan atau pengurangan impak negatif daripada risiko.

Kepentingan pengurusan risiko didapati telah meningkatkan dan dikenal pasti berkembang dengan lebih strategik bagi memperkukuhkan organisasi untuk mencapai objektif dari permulaan perancangan sehingga pelaksanaan (Fraser \& Simkins, 2016). Wilson-Grau (2003) menyebutkan bahawa ketidaktentuan persekitaran menuntut ITBK memaksimumkan peluang dan meminimumkan bahaya untuk berjaya.

Bagi ITBK mencapai misi dan objektif dalam jangka masa panjang, Wilson-Grau (2004) telah melaksanakan tahap strategik dalam pengurusan risiko. Gaudenzi et al. (2006) kemudiannya menggunakan model Analytical Hierarchy Process (AHP) untuk menilai risiko rantaian pembekalan. Chen (2012) pula telah menggunakan model matematik untuk mengira dan membandingkan situasi tidak berfungsi. Trivunovic et al. (2011) pula mengemukakan pendekatan komprehensif untuk menguruskan risiko disebabkan oleh korupsi. Proses pengurusan risiko yang lebih menyeluruh dalam ITBK kemudiannya telah dicadangkan oleh Ayvaz dan Pehlivanli (2010) dan dikenali dengan enterprise risk management (ERM) bertujuan memastikan pengurusan risiko dalaman dan luaran menyeberangi bahagian-bahagian organisasi.

Analisis risiko dalam institusi wakaf masih sedikit dilakukan oleh pengkaji-pengkaji lepas. Kajian Wan Ab Rahaman et al. (2020) merupakan kajian terkini yang telah mengkategorikan risiko dalam institusi wakaf secara sistematik berdasarkan tema yang diketengahkan oleh Domanski (2016). Kajian tersebut telah mengetengahkan enam jenis risiko berdasarkan kepada isu dan permasalahan yang berlaku dalam aktiviti pembangunan portfolio aset wakaf. Risiko yang dikenal pasti adalah risiko tadbir urus, pengoperasian, kewangan, pematuhan, reputasi dan undang-undang. Risiko tadbir urus dan pengoperasian dikenal pasti sebagai risiko utama yang menyebabkan risiko-risiko lain.

Bagi mendapatkan maklumat berkaitan kewujudan risiko dalam institusi wakaf Majlis Agama Islam Negeri (MAIN), analisis telah dilakukan ke atas empat buah institusi wakaf MAIN seperti Perbadanan Wakaf Negeri Selangor (PWS) yang mewakili zon tengah, Majlis Agama Islam Negeri Pulau Pinang (MAINPP) bagi zon utara, Majlis Agama Islam Johor (MAIJ) bagi zon selatan dan Majlis Agama Islam dan Adat Resam Terengganu (MAIDAM) untuk zon timur. Kajian mendapati, entiti-entiti tersebut masih belum mempunyai bahagian pengurusan risiko yang khusus. PWS sebagai contoh, mempunyai lima bahagian pengurusan iaitu bahagian kewangan, bahagian pemasaran dan dakwah, bahagian penyelidikan dan pelaburan dan unit audit dalam (Wakaf Selangor, 2021). Manakala Wakaf MAINPP meletakan urusan wakaf di bawah bahagian pengurusan hartanah dan wakaf. Di bawah bahagian tersebut terdapat tiga unit iaitu unit pengurusan $\&$ penyelenggaraan premis, unit pengurusan dana wakaf dan unit pembangunan hartanah dan harta wakaf (Wakaf Negeri Pulau Pinang, 2021). MAIDAM pula hanya mempunyai satu bahagian pengurusan wakaf di bawah tanggungjawab bahagian pengurusan mal (Wakaf Negeri Terengganu, 2021). Wakaf di MAIJ pula terdiri satu bahagian sahaja yang menguruskan wakaf iaitu bahagian wakaf di bahawa kawal selia bahagian zakat, baitulmal dan wakaf (Wakaf Negeri Johor, 2021).

Kelompangan utama dalam institusi wakaf adalah ketiadaan bahagian pengurusan risiko yang dapat berperanan untuk menyelesaikan risiko yang berlaku dalam organisasi. Kekangan ini merupakan penyumbang kepada risiko tadbir urus dan pengoperasian. Tambahan pula, kewujudan dan praktis pengurusan risiko dalam IBK atau ITBK masih mengguna pakai pendekatan yang tradisional atau silo sewaktu menguruskan risiko-risiko dalam institusi. Strategi pendekatan ini didapati melaksanakan 
pengurusan risiko secara berasingan dan bersendirian tanpa wujudnya koordinasi antara satu sama lain (Chapman, 2007).

Revolusi praktikal pengurusan risiko telah memuncak dengan pendekatan integrasi pengurusan risiko berdasarkan kerangka enterprise risk management (ERM) bagi memenuhi isu berkaitan kegagalan dan kelemahan sistem kawalan dalaman (Hayne \& Free, 2014). Mikes an Kaplan (2015) melihat ERM boleh dipertimbangkan sebagai pendekatan yang sistematik untuk menguruskan risiko. Penggunaan ERM telah dimulakan oleh institusi kewangan kemudiannya diikuti oleh industri pendidikan dan insurans dan telah membuka kepada pemeriksaan pengawal seliaan yang besar (Beasley et al., 2005).

Adaptasi ERM dalam pengurusan wakaf dilihat sebagai satu anjakan paradigma baru bagi organisasi menyusun portfolio risiko di samping fokus dapat ditingkatkan kepada mekanisme untuk meningkatkan tadbir urus dan pengurusan risiko. Hal ini kerana, perhatian terhadap pengorganisasian yang ditekankan oleh pendekatan ERM, iaitu pelantikan ketua pegawai eksekutif risiko dan merancakkan peranan ahli lembaga pengarah mampu memacu institusi tidak bermatlamatkan keuntungan seperti wakaf untuk lebih berdaya saing. Tambahan pula, integrasi antara pendekatan konvensional dan pendekatan kontemporari dengan memberikan fokus kepada objektif dan misi organisasi dan menonjolkan jawatan khusus untuk mengendalikan hal ehwal risiko merupakan ciri-ciri yang dibawa dalam ERM dan relevan untuk disesuaikan dalam konteks wakaf masa kini.

\section{Kesimpulan}

Amalan pengurusan risiko dan kepentingan menguruskan risiko ditegaskan dalam Islam secara jelas. Walau bagaimanapun, teknik dan pendekatan menguruskan risiko adalah bergantung kepada objektif dan matlamat organisasi yang mengaplikasikan pengurusan risiko tersebut. Pengurusan risiko dalam institusi bermatlamatkan keuntungan diberikan perhatian yang tinggi kerana risiko memberikan efek kepada untung dan rugi. Walau bagaimanapun, situasi tersebut berbeza dengan institusi tidak bermatlamatkan keuntungan disebabkan oleh fokus dan matlamat yang kompleks dan penglibatan pemegang berkepentingan yang pelbagai. Walaupun begitu, perhatian terhadap peranan pengurusan risiko dalam institusi tidak bermatlamatkan keuntungan mula mendapat perhatian daripada kalangan pengurusan institusi. Kajian ini turut meninjau organisasi wakaf dan mendapati masih belum terdapat bahagian pengurusan risiko yang khusus dalam organisasi. Situasi ini telah menampakkan kelompangan institusi jika dibandingkan dengan keperluan yang telah digariskan oleh syarak. Tambahan pula, berdasarkan kepada analisis keterdedahan risiko yang telah dikemukakan secara sistematik oleh pengkaji lepas, terdapat keperluan untuk mencadangkan kerangka pengurusan risiko bersandarkan pendekatan ERM. Hal ini kerana, keupayaan yang ditonjolkan oleh ERM mampu untuk memberikan penyelesaian terhadap situasi yang berlaku di dalam institusi wakaf pada masa kini.

\section{Rujukan}

Akkizidis, I., \& Khandelwal, S. K. (2008). Financial Risk Management for Islamic Banking and Finance. In Financial Risk Management for Islamic Banking and Finance.

Al-Saati, A. R. (2003). The Permissible Gharar (Risk) in Classical Islamic Jurisprudence. Islamic Economic Studies, 16(2), 3-19.

Al-Suwailem, S. (2001). Venture Capital: A potential Model Of Musharakah. Journal of King Abdulaziz University-Islamic Economics, 13(1), 61-62.

Al-Suwailem, S. (2013). Towards an Objective Measure of Gharar in Exchange. Islamic Economics Studies, 7(1 \& 2), 64-66.

Al-Zarqa', M. A. (1980). Nizam al-Ta'min: Mawqi'uh fi al-Maidan al-Iqtisadi bi Wajh 'Am wa Maqifu al-Shariah al-Islamiyyah minah.

Althaus, C. E. (2005). A disciplinary perspective on the epistemological status of risk. Risk Analysis, $25,567-588$.

Anheier, H. K. (2005). Nonprofit Organizations: Theory, Management, Policy. In Social Policy.

Aygun, O. O. (2007). The included middle: Logos in Aristotle's philosophy. Pennsylvania State 
University, State College.

Ayub, M. (2007). Understanding Islamic Finance (P. A. W. Pribadi (ed.). Gramedia Pustaka Utama.

Ayvaz, E., \& Pehlivanli, D. (2010). Enterprise Risk Management Based Internal Auditing. 5(1), 1-20.

Beasley, M.S., Clune, R. \& Hermanson, D. (2005). Enterprise risk management: an empirical analysis of factors associated with the extent of implementation. Journal of Accounting and Public Policy, 24(6), 521-531.

Bhatti, I., \& Misman, F. N. (2012). Risks Exposure in Islamic Banks: A Case Study of Bank Islam Malaysia Berhad (BIMB). SSRN Electronic Journal.

Boas, K. (2012). Building capacity in NGO risk management. Retrieved from http://www. thesustainablengo.org/.

Bougatef, K. (2015). The impact of corruption on the soundness of Islamic banks. Borsa Istanbul Review, 15(4), 283-295.

Bowman, W., Keating, E., Hager, M. (2007). Investment Income. In: Financing nonprofits, putting theory into practice. In Lanham: National Center on Nonprofit Enterprise and Rowman and Littlefield Publishers, INC edited by D. R. Young.

Carr, V., \& Tah, J. H. M. (2001). A fuzzy approach to construction project risk assessment and analysis: Construction project risk management system. Advances in Engineering Software, $32(10-11), 847-857$.

CAS. (2003). Overview on Enterprise Risk Management: Casualty Actuarial Society - Enterprise Risk Management Committee.

Chapman, R. (2007). Successful management of IT risk.

Chen, T.J. (2012). The impact of enterprise risk management on corporate governance and firm value. Working Paper of American Accounting Association Annual Meeting and Conference on Teaching and Learning in Accounting, 4-8 August, Washington, DC.

Clary, D. (1997). Six steps to good-reputation insurance. Nonprofit World, 15(1), 45-47.

Collier, P.M. \& Woods, M. (2011). A Comparison of the Local Authority Adoption of Risk Management in England and Australia. Australian Accounting Review, 21(2), 111-123.

Culp, C. L. (2002). The Revolution in Corporate Risk Management: A Decade in Innovations in Process and Products. Journal of Applied Corporate Finance, 14(4), 9-26.

Committee of Sponsoring Organizations of the Treadway Commission (COSO). (2004). Enterprise Risk Management - Integrated Framework. New York.

Dickinson, G. (2001). Enterprise risk management: Its origins and conceptual foundation. The Geneva Papers on Risk and Insurance, 2(3), 360-366.

Duncan, N. (2008). Risk management: How to protect your assets? Nonprofit World, 26(1), 25-28.

Dusuki, A. W., \& Smolo, E. (2009). Islamic hedging: Rationale, necessity and challenges. Proceeding International Seminar on Muamalat, Islamic Economics and Finance, 2009 (SMEKI' 09), 533552.

El Tiby, A. M. (2011). Islamic Banking: How to Manage Risk and Improve Profitability. In Islamic Banking: How to Manage Risk and Improve Profitability.

Elgari, M. A. (2003). Credit Risk in Islamic Banking and Finance. Islamic Economic Studies, 10(2).

Elsefy, H. (2007). Islamic Finance: a Comparative Jurisprudential Study. Penerbit Universiti Malay.

F. Ostrower, M. M. S. (2007). Governance: Research trends, gaps, and future prospects.

Fisher, D. (1983). The Role of Philanthropic Foundations in the Reproduction and Production of Hegemony: Rockefeller Foundations and the Social Sciences. Sociology.

Fraser, J. R. S., \& Simkins, B. J. (2016). The challenges of and solutions for implementing enterprise risk management. Business Horizons, 59, 689-698.

Gronbjerg, K. A. (1991). How nonprofit human service organizations manage their funding sources: Key findings and policy implications. Nonprofit Management and Leadership.

Habegger, B. (2008). Risk Management in Public Policy. International Studies Association 49th Annual Convention.

Hayne, C., \& Free, C. (2014). Hybridized professional groups and institutional work: COSO and the rise of enterprise risk management. Accounting, Organizations and Society, 39(5), 309-330.

Head, G.L., Herman, M.L. (2002). Enlightened risk taking, A guide to strategic risk manage- ment for nonprofit. Washington: Nonprofit Risk Management Center.

Hopkin, P. (2002). Holistic Risk Management in Practice.

Hubbard, D. (2009). The Failure Of Risk Management: Why It's Broken And How To Fix It. John 
Wiley\& Sons.

Ibn Taimiyyah, A., A., H., A., S. (1987). Al-Fatawa al-Misriyah. Dar al- Jil.

Ibn Taimiyyah, A., A., H., A., S. (1996). Tafsir Ayat Asykalata (M. Al-Rusyd (ed.).

Ibn al-Manzur, A. F. J. D. M. I. M. (2002). Lisan al-Arab. Kaherah. Dr al-Ma'arif.

Liebenberg, A.P \& Hoyt, R. (2003). The Determinants of Enterprise Risk Management: Evidence from the Appointment of Chief Risk Officer. Risk Management and Insurance Review, 6(1), 3752.

Ismail, A., \& Ahmad, M. A. J. (2010). Krisis Kredit Menurut Perspektif Pengurusan Risiko Islam : Bagaimana Syariah Memberikan Pengajaran Bernilai Untuk Kapitalis. Jurnal Muamalat, 3, 4775.

Iwankiewicz-Rak, B. (2006). Siła wizerunku organizacji pozarządowej (The Power of the Nongovernmental Organization's Image). Trzeci Sektor, 5, 30-36.

Jackson, M. O. (2010). Social and Economic Networks. In Social and Economic Networks.

Jorion, P. \& S. J. K. (1996). Financial Risk Management Domestic and International Dimensions. Blackwell Publishers. Cambridge: Massachusetts.

Kathir, I. (1999). Tafsir al-Quran al-'Azim. Dar Taiyibah.

Kearns, K. (2007). Income portfolios. In: Financing nonprofits, putting theory into practice. In D. R. Young (Ed.), Lanham: National Center on Nonprofit Enterprise and Rowman and Little-field Publishers, INC.

Khan, T., \& Ahmed, H. (2001). Risk management an analysis of issues in Islamic financial industry. 6(5), 193.

Knechel, W. R. (2002). The role of the independent accountant in effective risk management. Journal of Economics and Management, 47, 65-86.

Liu, J., Li, B., Lin, B., \& Nguyen, V. (2007). Key issues and challenges of risk management and insurance in China's construction industry: An empirical study. Industrial Management and Data Systems.

Matan, R., \& Hartnett, B. (2011). How Nonprofit Organizations Manage Risk. Sobel \& Co.

Mikes, A., \& Kaplan, R. S. (2015). When one size doesn't fit all: Evolving directions in the research and practice of enterprise risk management. Journal of Applied Corporate Finance, 27, 37-40.

Mitchell, V. (1995). Assessing the perceived risks associated with appointing planning consultants. Journal of Marketing Management, 11(1-3), 165-186.

Mohd Razif, N. F., \& Mohamad, S. (2011). Risiko-risiko dalam kewangan semasa: penilaian daripada perspektif Islam. International Conference on Management (ICM 2011), Icm, 373-387.

Nurhafiza, A. K. M. (2015). Islamic banking and risk management: Issues and challenges. Journal of Islamic Banking and Finance, Oct.-Dec., 64-71.

Othman, R., \& Ameer, R. (2014). Institutionalization of risk management framework in Islamic NGOs for suppressing terrorism financing. Journal of Money Laundering Control, 17(1), 96-109.

Rahman, R. A., Alsmady, A., Ibrahim, Z., \& Muhammad, A. D. (2014). Risk Management Practices In Islamic. The Journal of Applied Business Research, 30(5), 1295-1304.

Ramli, S. (2000). Pasaran Niaga Hadapan: Melindung Nilai dan Spekulasi. Utusan Publications \& Distributors Sdn.Bhd.

Redzuan, H., R. Y. \& M. A. H. (2006). Prinsip Pengurusan Risiko dan Insurans. Prentice Hall.

Rejda, G. E. (n.d.). Principles Of Risk Management And Insurance.

Rosly, S. A. (2005). Critical issues on Islamic banking and financial markets: Islamic economics, banking and finance, investments, Takaful and financial planning. Dinamas Publishing.

Said, F. F., \& Iglesias, E. M. (2017). Basel II and the financing of R\&D investments in Malaysia. International Journal of Economics and Management, 11(1), 127-152.

Shimpi, P. A., \& Lowe, S. P. (2006). Risk Management: ERM for Insurers. Risk Management, July 2006(8), 34-38.

Sollis, P. (1995). Partners in development? The state, nongovernmental organizations and the UN in Central America. Third World Quarterly, 16(3), 525-542.

Sundarajan, V. (2005). Risk measurement and disclosure in Islamic Finance and the implications of profit sharing investment accounts. 6th International Conference at Islamic Economics, Banking and Finance, Organized by Islamic Research and Training Institute- Islamic Development Bank, Bank Indonesia, and University of Indonesia.

Mohd Noor, S. N., M., Ismail, A. G., Hakimi, M., \& Shafiai, M. (2018). Shariah Risk: Its Origin , 
Definition, and Application in Islamic Finance.

Thompson, P. B. (1986). The philosophical foundations of risk. Southern Journal of Philosophy, 24, 273-286.

Trimpop, R. M. (1994). The Psychology of Risk Taking Behavior.

Trivunovic, M., Johnsøn, J., \& Mathisen, H. (2011). Developing an NGO corruption risk management system: Considerations for donors.

Trussel, J.M., Patrick, P. (2009). An empirical analysis of financial distress in Pennsylvania hospitals. Journal of Health Care Finance, 36(1), 31-60.

Van Staveren, M. (2009). Risk Innovation and Change.

Vaughan, E. (1997). Risk Management.

Wan Ab Rahaman, W. M. A. F., Yaacob, S. E., M. S. H. (2020). Pengurusan Pembangunan Portfolio Aset Wakaf: Keterdedahan Risiko dan Pengurusannya. Jcil, 5, 26-36.

West, D.C., Sargeant, A. (2004). Taking risks with advertising: The case of the not-for-profit sector. Journal of Marketing Management, 20(9), 1027-1045.

Wilson-Grau, R. (2003). The risk approach to strategic management in development NGOs. Development in Practice, 13(5), 533-536.

Zaidan, A. K. (2008). Al-Wajiz: 100 Kaedah Fikih dalam Kehidupan Sehari-hari (P. M. M. Rida (ed.); p. 183). Penerbit Pustaka Al-Kautsar.

Zapadka, P. (2007). Ryzyko prawne $w$ dziatalno- ści banków komercyjnych - wybrane zagadnie- nia (Legal risk in commercial banks - selected issues). Prawo Bankowe. 3(115), 30. 